\title{
Paleoclimatic inferences for the Holocene of southern Brazil in environments influenced by different hydrological systems
}

\author{
Gabrielli Teresa Gadens Marcona*®, Margot Guerra Sommerb®, João Graciano Mendonça- \\ Filhoco \\ a Universidade Estadual do Rio Grande do Sul, Porto Alegre, 91540-000, Rio Grande do Sul, Brasil. *gabrielli-marcon@uergs.edu.br \\ b Programa de Pós-Graduação em Geociências, Universidade Federal do Rio Grande do Sul, Porto Alegre, 91509-900, Rio Grande do \\ Sul, Brasil. \\ c Programa de Pós-Graduação em Geologia, Universidade Federal do Rio de Janeiro, Rio de Janeiro, 21941-916, Rio de Janeiro, \\ Brasil.
}

Received: October 18, 2019 / Accepted: December 8, 2019 / Published online: May 25, 2020

\begin{abstract}
Organic matter preserved in continental deposits is an excellent archive of environmental and climate change, and various research tools are commonly used to access this information. The present study is the result of a study conducted in continental environments influenced by different hydrological systems and demonstrates the usefulness of these analyses in obtaining rainfall-related paleoclimatic data. The study area is located in the basalts of the Alto Uruguai region (Rio Grande do Sul, Brazil), known for its mineral riches such as amethyst geodes and hot springs. The methodology used integrates palynofacies and organic geochemistry techniques, complemented by radiocarbon dating. The results were obtained from three sedimentary profiles and showed a trend of relative decrease in rainfall levels in the region. However, the scale of these changes is also highly influenced by the hydrological system of the depositional environment that originated the sedimentary record at each site. Based on the data obtained, we advise the establishment of medium- and long-term policies involving better management of local natural resources in the investigated region.
\end{abstract}

Keywords: Continental areas, palynofacies, turfeiras, organic matter, shallow lakes.

\section{Inferências paleoclimáticas para o holoceno do sul do Brasil em ambientes influenciados por diferentes sistemas hidrológicos}

\begin{abstract}
Resumo
A matéria orgânica preservada nos depósitos continentais é um excelente arquivo de mudanças ambientais e climáticas, e várias ferramentas de pesquisa são comumente usadas para acessar essas informações. O presente estudo é o resultado de um estudo realizado em ambientes continentais influenciado por diferentes sistemas hidrológicos e demonstra a utilidade dessas análises na obtenção de dados paleoclimáticos relacionados à chuva. A área de estudo está localizada nos basaltos da região do Alto Uruguai (RS), conhecida por suas riquezas minerais, como geodos de ametista e fontes termais. A metodologia utilizada integra palinofácies e técnicas de geoquímica orgânica, complementadas por datação por radiocarbono. Os resultados foram obtidos a partir de três perfis sedimentares e mostraram uma tendência de diminuição relativa nos níveis de chuva na região. No entanto, a escala dessas alterações também é altamente influenciada pelo sistema hidrológico do ambiente deposicional que originou o registro sedimentar em cada local. Com base nos dados obtidos, aconselhamos o estabelecimento de políticas de médio e longo prazo que envolvam melhor gerenciamento dos recursos naturais locais na região investigada.
\end{abstract}

Palavras-chave: Área continental, palinofácies, peat bogs, matéria orgânica, lagos rasos.

\section{Introduction}

In sedimentary rocks, organic matter represents the smallest portion of the sedimentary fraction and derives directly or indirectly from the organic part of organisms (Ruiz et al., 2012). The presence of organic compounds in the sediment is due to a series of biological, physical, chemical, and geological factors interrelating in the production, accumulation, and preservation of organic matter and is part of the organic carbon cycle in nature (Mendonça-Filho et al., 2010).

According to Souza et al. (2016), the study of the organic matter present in sediments of coastal and marine areas has been widely used in the reconstruction of environmental evolution in different regions of Brazil. For Ramirez et al. (2018), marginal basins play an important role in understanding depositional processes such as those involved in the opening of the Atlantic Ocean when South America 
separated from Africa. The analysis of the organic matter present in such basins is also used in the exploitation of oil deposits, which justifies the fact that research on continental rocks and sediments is still scarce compared to marine ones.

According to Marcon et al. (2014a), organic matter preserved in deposits from strictly continental environments is an excellent archive of changes in the depositional, environmental, ecological, and climatic conditions under which these deposits originated. Various research tools are often used to access this information, highlighting palynofacies analysis and organic geochemistry.

Tyson (2012) states that palynofacies analysis comprises the qualitative and quantitative characterization of particulate organic matter, which is subdivided into three main groups: phytoclasts, palynomorphs, and amorphous organic matter (AOM). Each individual organic particle behaves like a sedimentary particle and, therefore, palynofaciological analyses are based on the relative abundance of such particles (Menezes et al., 2008). Geochemical studies, including total organic carbon (TOC) analysis, provide data on the amount and state of preservation of the organic matter present in the depositional system. These studies constitute an important parameter to determine the organic content in sedimentary rocks and serve as a complementary tool for palynofaciological analysis (Mendonça-Filho et al., 2010, 2011).

In the present study, palynofaciological and organogeochemical analyses were performed in the study of sediments coming from shallow lakes (in Ametista do Sul) and from a peat bog (in Iraí), both located in the Alto Uruguai region (northwestern RS) and with correlated ages. In this sense, we demonstrate the usefulness of these analyses in obtaining rainfall-related paleoclimatic data. The data also allowed to evaluate the extent of the influence of hydrological regimes on the studied environments, adding new information to the previously inferred paleoclimatic and paleoenvironmental interpretations.

\section{Material and Methods}

The study area lies in the basalts of the Serra Geral Formation (Paraná Volcano-Sedimentary Basin), located in the Alto Uruguai region, Rio Grande do Sul State (RS). This area is known worldwide for its mineral riches, such as amethyst geodes in Ametista do Sul and hot springs in Iraí (Duarte et al., 2009).

Although Ametista do Sul and Iraí are neighboring cities distant about 32 kilometers from each other, the sampled area of Iraí is often affected by the floods of the Uruguay River, which does not happen in Ametista do Sul, as the city is located on hilltops and is not influenced by other adjacent water bodies. This contrast is therefore due to differences in relief, given that Iraí is located in a lower area (at river level) than Ametista do Sul.

The two shallow high-altitude lakes selected correspond to the first type of silica gossan described by Hartmann et al. (2010). These water bodies are surrounded by native vegetation and dry up in times of prolonged drought. Both lakes are located at hilltops, with two amethyst extraction mines just below them. Fourteen samples of sedimentary profile $\mathrm{T} 1(65 \mathrm{~cm}$ deep) and seventeen samples of profile T2
(80 $\mathrm{cm}$ deep) were used for the analyses. The profiles were identified as T1 - Museum Mine (27 $22.373^{\prime} \mathrm{S} x 5^{\circ} 11.901^{\prime}$ $\mathrm{W})$ and T2 - Model Mine $\left(27^{\circ} 19.536^{\prime} \mathrm{S}\right.$ x $\left.53^{\circ} 13.579^{\prime} \mathrm{W}\right)$, which are the names popularly given to the amethyst extraction mines located below the sites where these sedimentary profiles were extracted.

In addition to hot springs containing mineral water, Iraí comprises a peat bog area with a surface layer richer in sediment and water, popularly known in the region as "medicinal mud". It is a dark sediment with a characteristic odor and rich in organic matter, which is extracted from a well that is opened for commercial purposes in a marsh area. This "mud" has been used therapeutically for decades in the town resorts. Although being economically exploited, it has not yet had its medicinal properties scientifically proven. In the present study, we analyzed 25 samples from a $115 \mathrm{~cm}$ deep sedimentary profile extracted from the bog area described above and identified as T3 - Iraí (27 '10’822” S x 5314'980" W).

Sedimentary profiles T1, T2, and T3 were collected in triplicate from a single collection performed at each point during the first semester of 2009. For the drilling of sedimentary deposits, PVC and aluminum pipes (one to two meters deep; diameter between 7 and $10 \mathrm{~cm}$ ) were used. Once collected, the profiles were packaged and taken to the Sedimentology Laboratory of the Coastal and Oceanic Geology Studies Center (CECO) of the Geosciences Institute (IGeo) of the Federal University of Rio Grande do Sul (UFRGS). Then, they were properly opened, fractionated, repackaged, and sent to laboratories for specific analyses or for preparing the samples for analysis.

To make organopalynological slides, the samples were chemically processed at the Laboratory of Palynofacies and Organic Facies (LAFO), Institute of Geology (IG), Federal University of Rio de Janeiro (UFRJ), according to the nonoxidative palynological procedures described by Tyson (2012) and Mendonça-Filho et al. (2010, 2011, 2012). The steps are described below.

To prepare the particulate organic matter (POM) concentrate, the studied samples were ground to the approximate size of $2 \mathrm{~mm}$. The samples were treated successively to remove carbonates $(37 \% \mathrm{HCl}$ for $18 \mathrm{~h})$, silicates $(40 \% \mathrm{HF}$ for $24 \mathrm{~h}$ ), and newly formed fluorides $(37 \% \mathrm{HCl}$ for $3 \mathrm{~h})$. Between steps, the samples were washed with distilled water until the wash water was neutral. After this procedure, dense liquid $\left(\mathrm{ZnCl}^{2}\right.$; density $=1.9$ to $\left.2 \mathrm{~g} / \mathrm{cm}^{3}\right)$ was added and stirred, and the samples were centrifuged to separate sulfides. The floating material was similarly washed and drops of $10 \% \mathrm{HCl}+$ distilled water were added to remove residual heavy liquid. The isolated organic matter was sieved at $20 \mu \mathrm{m}$. After this procedure, the slides with the organic residue were prepared.

The counting and classification of particulate organic matter is based on the classification system proposed by Tyson (2012) and Mendonça-Filho (2010, 2011, 2012), being performed under transmitted white light microscopy and incident ultraviolet-blue light (HBO 100 W; fluorescence). The counting considers all organic matter between 300 and 500 particles. Among the three main 
groups, phytoclasts represent the remains derived from higher vegetables; palynomorphs are the reproductive particles (pollen grains and spores) of plants and other species capable of producing such structures; and amorphous organic matter (AOM) are all particles that appear unstructured under the microscope in view of their advanced stage of degradation. The counting was performed at the LAFO/UFRJ Laboratory and at the Paleobotany Sector Laboratory of the UFRGS Department of Paleontology and Stratigraphy.

After counting particulate organic components, statistical treatment was performed. The scatter plots presented in the results were generated using the C2 Data Analysis program (version 1.7.2). From the percentage of algal spores found in each layer, it was possible to generate a scatter plot that expresses the water level in the lakes at each season. These plots are expressed in Figures 2 and 3.

After acidification to remove carbonates, TOC (Total Organic Carbon) and TS () analyses were performed on all samples. The equipment used was a LECO SC 144DR analyzer, which simultaneously quantifies carbon and sulfur contents through an infrared detector. The analyses were performed at LAFO/UFRJ, following the standards of ASTM D 4239 (American Society Testing and Materials, ASTM, 2008) and NCEA-C-1282 (United States Environmental Protection Agency, USEPA, 2002).

Radiocarbon dating used the AMS (Accelerator Mass Spectrometry) technique and was performed by the Beta Analytic Radiocarbon Dating Laboratory (Miami, Florida, USA). In the text and images, the Conventional Radiocarbon Age is cited as "BP" (Before Present), and the word "Present" refers to the year 1950 of the Christian Era for radiocarbon dating purposes. All ages mentioned for sedimentary profiles T1, T2, and T3 were calibrated (INTCAL04).

For sedimentary profile $\mathrm{T} 1$, three radiocarbon dating procedures were performed, corresponding to the depth intervals of 65,40 , and $20 \mathrm{~cm}$. The other ages that appear in the results, between 65 and $20 \mathrm{~cm}$, were interpolated, and those that appear from $20 \mathrm{~cm}$ to the top were extrapolated.

All interpolated/extrapolated ages were calculated using the conventional mean age range intercept on the $14 \mathrm{C}$ calibration curve (CALIB version 4.3; Stuiver et al., 1998).

For sedimentary profile $\mathrm{T} 2$, three radiocarbon dating procedures were performed, corresponding to the depth intervals of 80,45 , and $15 \mathrm{~cm}$. The same interpolation and extrapolation procedure was used for the other ages displayed in the results. For sedimentary profile T3, two radiocarbon dating procedures were performed, one at the base $(115 \mathrm{~cm})$ and the other at the $15 \mathrm{~cm}$ interval. The same procedure used for profiles T1 and T2 was applied for the ages of the other intervals.

\section{Results and Discussion}

The comparison between results showed that the vegetation of the analyzed environments developed differently. While in Ametista do Sul the diversity and abundance of vegetation increased towards the Recent, in Irai the vegetation associated with the depositional environment decreased in these two aspects. The evaluation of vegetation diversity in Ametista do Sul was estimated by the increasing patterns of spore and pollen grain diversification. For Iraí, in turn, loss of diversity could be inferred by the progressive reduction of epidermal organization of the cuticles present in the sediment.

In Ametista do Sul, the vegetation developed concomitantly with the sedimentation of shallow lakes at hilltops, where the process of ecological succession led to increased vegetation diversity. Hilltop areas are difficult to reach and thus do not generate economic interest, which kept the area protected from anthropogenic interference until the moment of the study.

The same successional process could not be observed in Iraí, as the early vegetation was more exuberant than that currently preserved at the site. Removal of vegetation for medicinal mud extraction resulted in a landscape currently dominated by grasses and a few trees. This anthropogenic interference with the surroundings of the study area can be observed in the sedimentary record, especially from the 15 $\mathrm{cm}$ depth - which corresponds to the last 101 years BP - to the shallowest layer (top). From this point it becomes difficult to distinguish the natural causes of anthropogenic interference in the system, not only because there is a significant reduction in cuticle epidermal organization patterns, but because the carbon/sulfur ratio increases greatly in these layers, where TOC and TS intervals are between the lowest of the entire sedimentary profile. Possibly the anthropogenic activities of water drainage for extraction of medicinal mud near the well are affecting the most superficial layers of the peat bog, resulting in an oxidation interval whose causes are not of natural or climatic origin, but rather could be of cultural origin. In the long term, measures to drain well water and remove surrounding vegetation may compromise the sustainability of the peat bog and, consequently, the maintenance of the "medicinal mud" resource.

Palynofacies analysis was particularly effective in the interpretation of rainfall events and vegetation succession for shallow high-altitude lakes in Ametista do Sul. The significant variation in algal frequencies in the study sites was decisive for paleoclimatic interpretations.

Comparative analysis of Figures $2 \mathrm{~A}$ and $2 \mathrm{~B}$ indicates that there was generally more moisture in the past (early and middle Holocene), subsidized by high rainfall events.

The more intense rainfall events inferred from palynofacies analysis could be correlated to Bond events (Bond et al., 1997; Bond et al., 2001), especially 9.4 ka, 8.2 ka, and 7.4 ka events (Marcon et al., 2014 a, b). Water accumulation in the gossan and the onset of sedimentation of lakes in Ametista do Sul would have been a consequence of such events (Marcon et al., $2014 \mathrm{a}, \mathrm{b}$ ).

Sedimentary profile T1 - Museum Mine is estimated to be 7,963 years BP (average probability), or about $8.0 \mathrm{ka}$. Figure 2 shows three rainfall peaks at ages $7.6 \mathrm{ka}, 6.5 \mathrm{ka}$, and $5.9 \mathrm{ka}(60,45$, and $30 \mathrm{~cm}$ deep, respectively). However, the entire period from $8.0 \mathrm{ka}$ (Base) to $5.7 \mathrm{ka}(25 \mathrm{~cm})$ is marked by high rainfall. From $5.6 \mathrm{ka}(20 \mathrm{~cm})$ the water level of the lake decreases, being progressively below average until the Recent (top). The lake in profile T1 may have acquired the current metabolism with intermittent long droughts (Figure 2A) five thousand years ago. 

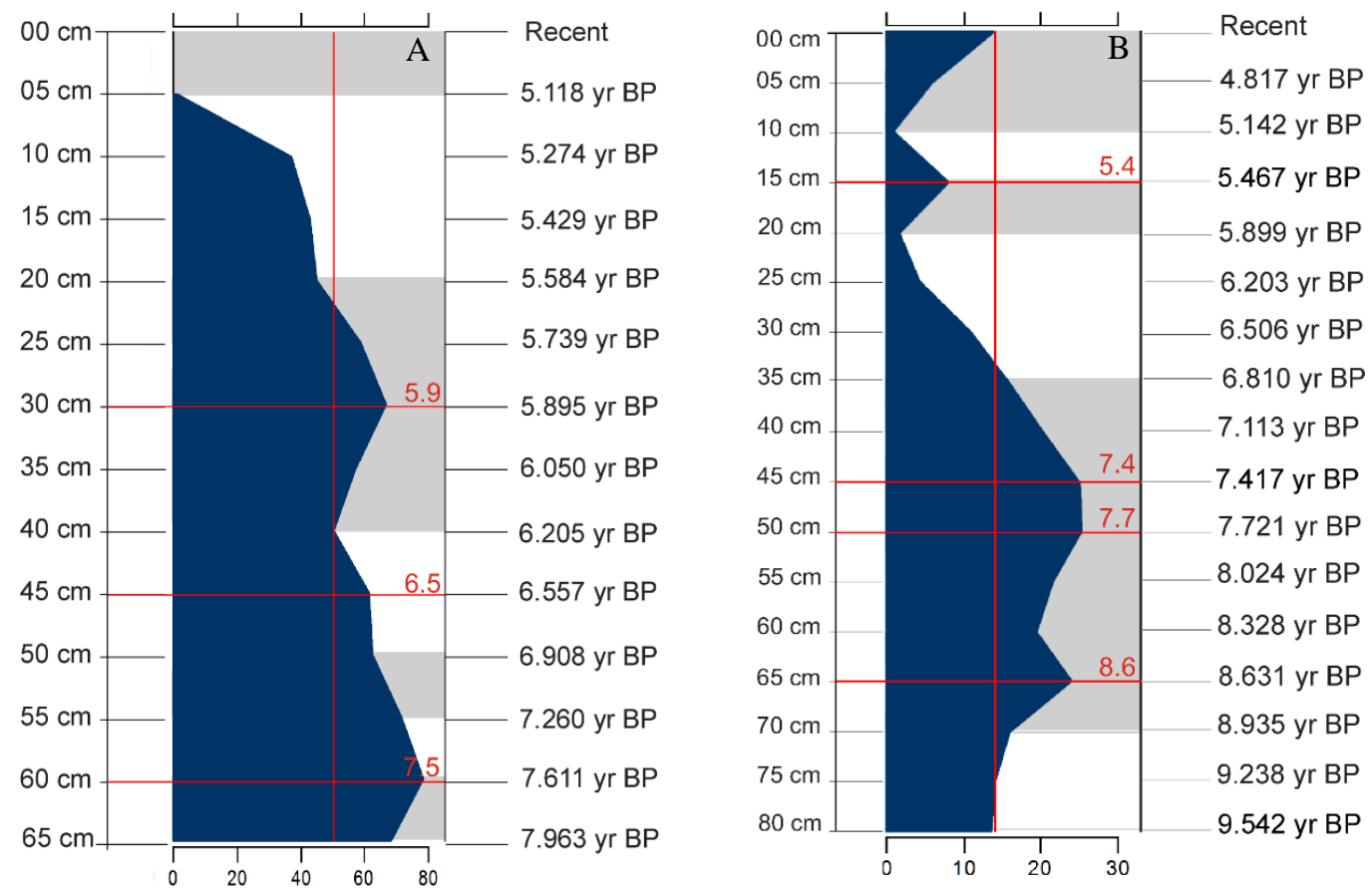

Figure 2. Sedimentary profiles of T1 - Museum Mine (A) and T2 - Model Mine (B), demonstrating variations in the water level of the wetland throughout the Holocene, in addition to rainfall peaks (horizontal red lines). Time period in years before present (yr BP).

Sedimentary profile T2 - Model Mine is 9,542 years BP (average probability), or about $9.5 \mathrm{ka}$. Figure 2B shows rainfall peaks at ages such as $8.6 \mathrm{ka}, 7.7 \mathrm{ka}, 7.4 \mathrm{ka}$, and $5.4 \mathrm{ka}$ $(65,50,45$, and $15 \mathrm{~cm}$ deep, respectively). As in the previous sedimentary profile, it also has a period of high rainfall, from $9.2 \mathrm{ka}$ to $6.8 \mathrm{ka}$; after this period, the water level of the lake decreases. A rainfall peak occurs again at $5.4 \mathrm{ka}$, and another closest to the Recent. Notwithstanding, although deeper than the Museum Mine, currently the Model Mine lake also dries out under prolonged droughts (more than four months without rain). As in the T1 profile lake, it was around five thousand years ago that the $\mathrm{T} 2$ profile lake began to have an intermittent drought regime (Figure 2).

High rainfall events occur between $9.2 \mathrm{ka}$ and $5.4 \mathrm{ka}$, and events that coincide between the two lakes date from approximately $8.0 \mathrm{ka}$ to $6.0 \mathrm{ka}$. At the beginning of their sedimentation, these water bodies were not intermittent, as there was enough moisture for them to remain saturated with water. The Museum Mine lake, being shallower, had a shorter cycle $(7,963$ years BP), while the Model Mine lake, being somewhat deeper, had a longer cycle $(9,542$ years BP). The depth of each of these wetlands also influenced the continuity of the record, which appears to have been closed by the almost complete sedimentation of the Museum Mine lake, but still goes on in the Model Mine lake.

The main difference between the records of these two shallow lakes is in the top layers. While for the Model Mine lake there are records of continuity of rainfall events for the Recent (though less intense and more unregulated than in the past), for Museum Mine lake there is the establishment of a growing and continuous phase of major drought towards the Recent. The Museum Mine lake is currently heavily filled with sediment, although it still remains saturated with water during the rainy season. However, it can be inferred that compared to the past, this lake may be succumbing to its own sedimentary metabolism (Esteves, 2011). This fact may be influencing the Recent record to the point that the water depth is not sufficient to accumulate a significant algal biota to compose the fossil record, for example. In this case, the lake may be lacking depth to accumulate algae, but not necessarily lacking rain. On the other hand, in the case of T2 - Model Mine, it is possible to notice that the lake still accumulates a reasonable biota of freshwater algae, but the water level has been oscillating below the average from 6.8 thousand years ago to the Recent, showing that the high rainfall levels from the early Holocene have not been repeated in the last five thousand years at least.

In any case, it can be safely stated that by virtue of their isolated hilltop position, the shallow high-altitude lakes of Ametista do Sul act as a meteoric water catchment tank and thus provide reliable data on rainfall events, being excellent records of past rainfall, similar to speleothems (Bernal et al., 2016; Strikes et al., 2011) and other high-resolution proxy records (Sallum et al., 2012).

In Iraí sediments, the best represented organic fraction consists of elements derived from terrestrial plants, a typical characteristic of organic matter preserved in peat bogs. Organogeochemical parameters were particularly useful in the interpretation of anoxia and hydrological events for the peaty sediments of Iraí, which responded better to these analyses because they had a much higher amount of organic carbon and sulfur in their constitution when compared to the sediments of the shallow lakes of Ametista do Sul.

Profile T3 - Iraí is 10,586 years old (average probability), or about $10.5 \mathrm{Ka}$. Due to the different hydrological regime, it was not possible to verify in this profile the same rainfall events of the sedimentary profiles of Ametista do Sul. In this 
type of environment, peat and humid, moisture contents were subsidized by different variables, such as the water table, rainwater, or the Uruguay River overflow events. Therefore, no drought has dried the place completely, because when a variable "failed", it was compensated by another. The very low frequency of algae, however, indicates that the water depth was not great enough for the development of this type of biomass, although the reducing and anoxic environment of the peat bog may also have limited the expansion of this group.

The period between $10.5 \mathrm{ka}$ and $6.4 \mathrm{ka}(115$ to $75 \mathrm{~cm})$ is characterized by the strong influence of the water table and rainfall, and the period from $5.8 \mathrm{ka}$ to the Recent was increasingly influenced by the Uruguay River overflow events (Figure 3).

In the period between $10.5 \mathrm{ka}$ and $8.9 \mathrm{ka}$ (from the base until $99 \mathrm{~cm}$ ), TOC and TS contents are very high, indicating the presence of a highly reducing, anoxic, and stagnant environment, typical of a peat bog. However, the presence of algae, even if extremely low, indicates that the rainfall of this period may have contributed a certain amount of water to the environment (Figure 3). From the $95 \mathrm{~cm}$ layer $(8.5 \mathrm{ka})$, the algae biota disappears, an event that may be related to a "sulfur anomaly" occuring in the anterior layer, $99 \mathrm{~cm}$ deep (8.9 ka). So far it has not been possible to unravel what has led to this abrupt increase in sulfur levels in the sediments. According to Marcon et al. (2014c), its origin may be associated with volcanism events (Naranjo \& Stern, 2004) or mineral water with large amounts of sulfates from hot springs in the region (Freitas, Roisenberg \& Andriotti, 2016).

The period between $8.5 \mathrm{ka}$ and $6.4 \mathrm{ka}$ (95 to $75 \mathrm{~cm}$ ) infers a predominance of a highly reducing, stagnant, and anoxic environment due to complete absence of algae in the sediment. It is believed that these were the characteristics that prevented the development of these microorganisms rather than lack of moisture, since TOC contents remained high, indicating that there was no oxidation of organic matter (Figure 3). Moisture was maintained by the water table and the peat bog remained isolated from the Uruguay River for some time.

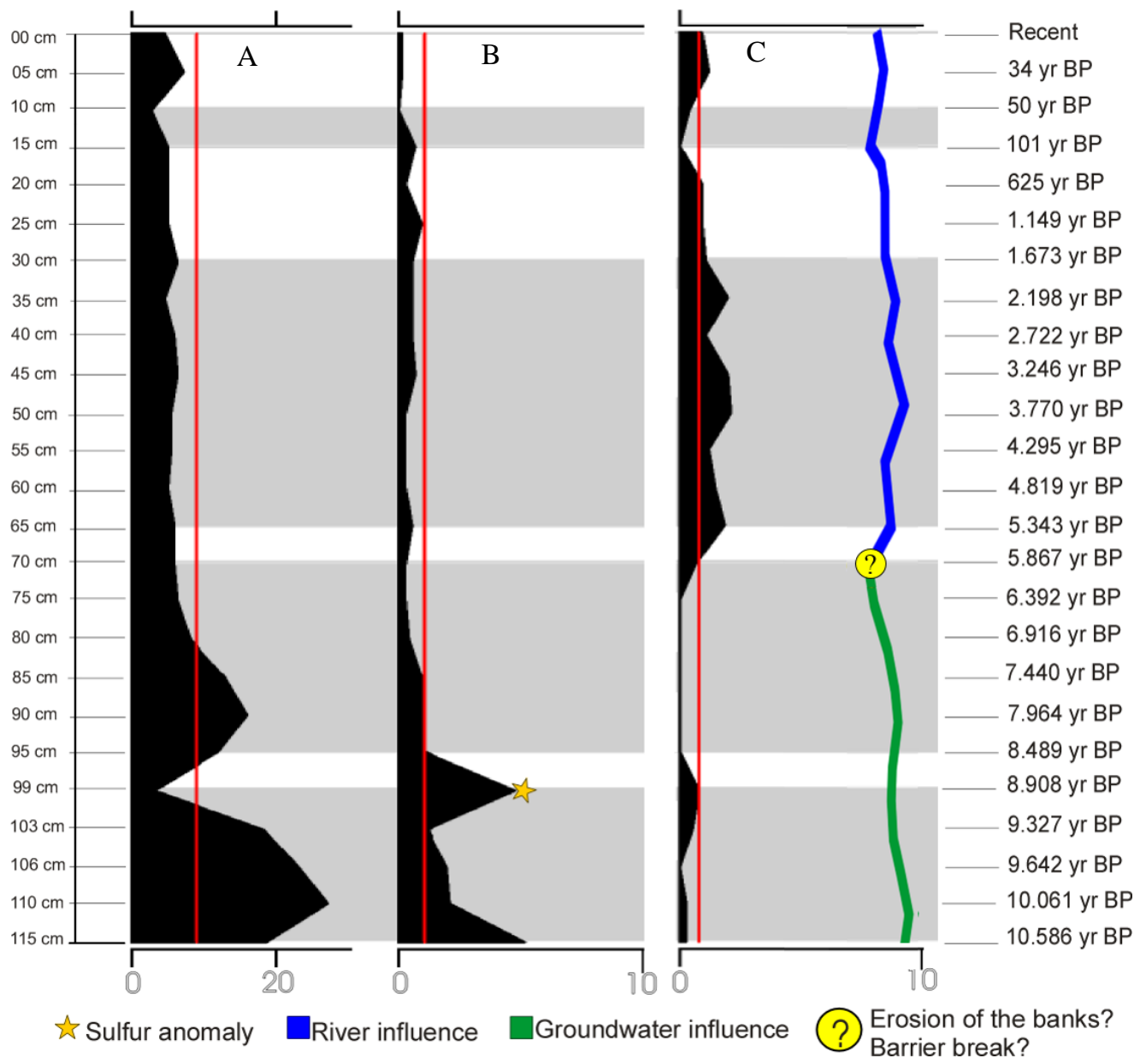

Figure 3. Variation in total organic carbon - TOC (A) and total Sulfur - TS (B) contents and in the algal percentage (C) of T3 - Iraí. The green curve represents the predominant nonfluvial hydrological regime (water table, rainfall). The blue curve represents the duration of the fluvial hydrological regime (Uruguay River). The yellow circle between the two curves indicates the time when the hydrological validity possibly changed and the question mark infers the possible causes of this change.

The event that occurred between $5.9 \mathrm{ka}(70 \mathrm{~cm})$ and the Recent was characterized by a higher predominance of algae groups. This indicates a significant increase in water supply, possibly from the overflow of the Uruguay River (Figure 3), which became connected with the study area (currently the area is flooded at times when the Uruguay River overflows). 
The period of higher water input to the peat bog in Iraí is associated with the Uruguay River overflow events, which begin to predominate at a depth of $70 \mathrm{~cm}$ (5.9 years BP), possibly due to the river bed approaching the depositional area by erosion of the banks and/or removal of any previously existing barrier between the river and the peat environment (Figure 3). These flooding events eventually introduced more water and more sediment than usual into the depositional environment. At first, the increase in the number of algae may give the impression that the increase in water supply was simply caused by more intense rainfall. If we used the same criteria as those applied in the interpretations of Ametista do Sul, this would probably be the outcome. However, the significant increase in sedimentation in the peat bog indicates a source of a different nature for Iraí.

The increasingly frequent inflows of the Uruguay River into the area and the increase in water supply eventually made the peat bog gradually more fluid near the surface. Hence, in the base-top direction, the typical characteristics of a "peat" are replaced by those of a "peaty sediment", i.e., the silica organic mud with "medicinal properties", as the "medicinal mud" from Iraí is popularly known.

The input of river water into the depositional area possibly contributed to an additional moisture in the system, diluting the organic content of the sedimentary deposit, which resulted in the consequent reduction of TOC and TS contents in the sediment and an increase in the number of algae elements, giving the impression of increasing rainfall levels from the last 5,900 years until the Recent. Although the presence of algae elements has been reported in the peat bog of Iraí, it is quite insignificant when compared to the shallow lakes of Ametista do Sul, since these are different environments. Therefore, the algae group does not allow to infer a water level for the peat bog of Iraí due to its low frequency. In any case, its presence, associated with other factors already described, may indicate the moment when the Uruguay River began to interfere with the area.

It is also possible to infer that the Uruguay River overflow episodes are associated with increased rainfall. In this case, the events in Iraí would indicate that the period of increased rainfall began 5,900 years ago, extending to the Recent. Such results do not completely agree with those obtained for Ametista do Sul. Although the T1 - Museum Mine also indicates a rainfall peak 5,900 years ago, the general trend shown by the two sedimentary profiles (T1 and $\mathrm{T} 2$ ) is a relative reduction in rainfall over the last five thousand years at least.

The discrepancy between the periods of higher moisture, inferred for Ametista do Sul and Iraí, may be directly related to the type of depositional environment and the predominant hydrological regimes in each of these areas. In Iraí, the depositional environment is sometimes subsidized by water from the water table, by rainwater, and by the waters of the Uruguay River, but at no time is there a record of drought, since this is an open environment continuously subsidized from various moisture sources. In contrast, we have the closed depositional environment of Ametista do Sul, whose moisture level depends exclusively on rainfall. The topographic position of each of the analyzed areas also has a great influence on the record, since the hydrological isolation of the Ametista do Sul lakes is a result of their location on hilltops. The peaty sediments of Iraí, on the other hand, are located in a low relief area close to river banks, which makes this depositional system more exposed to different influences. In this case, the Uruguay River overflow could be the result of a rainfall peak which 5,900 years ago broke or eroded a barrier that possibly existed between this watercourse and the area in question; later, minor flooding events had no difficulty accessing the area.

From these inferences, the interpretation of a trend of relative decrease in rainfall is maintained based on data provided by the sedimentary profiles of Ametista do Sul, since the predominant hydrological regime in the shallow lakes of that area allows the compilation of rainfall data somewhat more accurate than in Iraí, for the reasons already described.

The results obtained in relatively close research areas, such as the shallow lakes of Ametista do Sul and the peaty sediments of Iraí, were differentiated because in strict continental environments, where sedimentary deposits cover small areas, the climate influence is much greater than in marine or coastal environments, whose sedimentary deposits cover large areas. This evidence confirms that climate generalizations in continental environments should be based on research from more than one study area, preferably encompassing several areas within the same region for a more accurate resolution of the climate and environment changes occurred.

In continental environments, characterized by areas of limited extent, the data usually fluctuate widely due to the variables present in that particular depositional system. By virtue of this, the results obtained by different studies in such environments, using the most varied proxy data, may lead to divergent results; hinder the matching of the surveyed data; and even prevent a positive analogy between the studied depositional environments, in which radiometric age may be the only corresponding data.

Finally, paleoenvironmental, paleoecological, and paleoclimatic generalizations should consider the particular characteristics of the continental environments being analyzed, seeking explanations for the divergent results found through comparisons between the different variables that act on the depositional systems studied. Therefore, distinct depositional environments may respond differently to the same variables, not necessarily meaning contradictions in the record. Such findings can also be extrapolated to analogous environments from the geological past to allow for better integration of seemingly unrelated contemporary data.

\section{Conclusion}

The analyses carried out in Ametista do Sul showed a relative reduction of local rainfall, which allows us to predict the possibility of a progressive water stress for that region, being advisable the establishment of medium- and long-term policies involving a better management of local water resources. If the findings of this study extend to other lakes associated with silica gossans in the region, the future scenario of local water stress may become the object of more 
urgent and in-depth studies.

The analyses performed in Iraí showed a change in the characteristics of the peaty sediment, caused initially by fluvial action (70 to $15 \mathrm{~cm}$ ) and later by anthropogenic action (from $15 \mathrm{~cm}$ to the top). Oxidation of the surface layers of the peat bog allows us to predict progressive loss of the organic and geochemical content that possibly confers to the "medicinal mud" its therapeutic properties. Therefore, it is advisable to establish policies for proper management of such resource, at the risk of the city losing this source of complementary income in the medium and long term.

\section{References}

American Society for Testing and Materials (ASTM), 2008. Standard test methods for sulfur in the analysis sample of coal and coke using hightemperature tube furnace combustion methods ASTM 4239. Available on http://engineers.ihs.com/documents/abstract/NWETIBA.

INTCAL04 Radiocarbon Age Calibration. IntCal04: Calibration Issue of Radiocarbon (Volume 46, nr. 3, 2004).

Bernal, F. J. P.; Cruz, F. W.; Stríkis, N. M.; Wang, X.; Deininger, M.; Catunda, M. C. A.; Ortega-Obregón, C.; Cheng, H.; Edwards, L.; Auler, A. (2016). High-resolution Holocene South American monsoon history recorded by a speleothem from Botuverá Cave, Brazil. Earth and Planetary Science Letters, 450, 186-196. doi: 10.1016/j.epsl.2016.06.008

Bond, G.; Showers, W.; Cheseby, M.; Lotti, R.; Almasi, P.; Demenocal, P.; Priore, P.; Cullen, H.; Hajdas, I.; Bonani, G. (1997). A pervasive millennial-scale cycle in North Atlantic Holocene and glacial climates. Science, 278(5341), 1257-1266. doi: 10.1126/science.278.5341.1257

Bond, G.; Kromer, B.; Beer, J.; Muscheler, R.; Evans, M.N.; Showers, W.; Hoffmann, S.; Lotti-Bond, R.; Hajdas, I.; Bonani, G. (2001). Persistent solar influence on North Atlantic climate during the Holocene. Science. 294(5549): 2130-2136. doi: 10.1126/science.1065680

Duarte, L.C.; Hartmann, L.A.; Vasconvellos M.A.Z.; Medeiros, J.T.N.; Theye, T. (2009). Epigenetic formation of amethyst-bearing geodes from Los Catalanes gemological district, Artigas, Uruguay, southern Paraná Magmatic Province. Journal of Volcanology and Geothermal Research, 184(3-4), 427-436. doi:10.1016/j.jvolgeores.2009.05.019

Esteves, F. A. (2011) Fundamentos de Limnologia. (3a. Ed.). Rio de Janeiro: Interciência.

Freitas, M.A.; Roisenberg, A. \& Andriotti, J. L. S. (2016). Análise exploratório de dados da condutividade elétrica na águas do sistema aquífero Serra Geral no Rio Grande do Sul e Santa Catarina. Águas Subterrâneas, 30(1), 1-17. doi: 10.14295/ras.v30i1.28518

Hartmann, L. A.; Wildner, W.; Duarte, L. C.; Duarte, S. K.; Pertille, J.; Arena, L. C.; Martins, K. R.; Dias, N. L. (2010). Geochemical and scintillometric characterization and correlation of amethyst geode-bearing Paraná lavas from the Quaraí and Los Catalanes districts, Brazil and Uruguay. Geological Magazine, $\quad$ 147(06), 954-970. doi: $10.1017 / \mathrm{S} 0016756810000592$

Marcon, G. T. G.; Mendonça-Filho, J. G.; Guerra-Sommer, M.; Carvalho, M. A.; Pires, E. F.; Hartmann, L. A. (2014a). Relation between the sedimentary organic record and the climatic oscilations in the Holocene attested by attested by paylinofacies and organic geochemical analyses from a pond of altitude un southern Brazil. Annals of the Brazilian Academy of Sciences, 86(3), 1077-1099. doi: 10.1590/00013765201420130268

Marcon, G. T. G.; Guerra-Sommer, M. Mendonça-Filho, J. G.; Mendonça, J. O.; Carvalho, M. A.; Hartmann, L. A. (2014b). Holocene Environmental Climatic Changes based on Palynofacies and Organic Geochemical Analyses from an Inland pond at Altitude in Southern Brazil. American journal of Climate Change, (3), 95-117. doi: 10.4236/ajcc.2014.31009

Mendonça-Filho, J.G.; Menezes, T.R.; Mendonça J.O.; Oliveida, A.D.; Carvalho, M.A.; Sant'Anna, A.J.; Souza, J.T. (2010). Palinofácies. In: Carvalho, I.S. (Ed.). Paleontologia (3a. Ed). Rio de Janeiro: Interciência, (01): 289-323.

Mendonça-Filho, J.G.; Menezes, T.R.; Mendonça, J.O. (2011). Organic Composition (Palynofacies Analysis). In: Vasconcelos, L.; Flores, D.; Marques, M (Org.). 4th ICCP Course in Dispersed Organic Matter. Porto: Plenimagem, cap. 5, p. 33-81.

Mendonça Filho, J. G.; Menezes, T. R.; Mendonca, J. O.; Oliveira, A. D.; Silva, T. F.; Rondon, N. F.; Silva, F. S. (2012). Organic Facies: Palynofacies and
Organic Geochemistry Approaches. In: Dionisius Panagiotaras (Ed.). Geochemistry - Earth and System Processes. Croatia: InTech, p. 211245.

Menezes. T.R.; Mendonça-Filho, J.G.; Araújo, C.V.; Souza, I.V.A.F.; Mendonça, J.O. (2008). Fácies orgânica: conceitos, métodos e estudos de casos na indústria do petróleo. Revista Brasileira de Geociências, , 38(2): $\quad 80-96 . \quad$ Recovered from http://www.ppegeo.igc.usp.br/index.php/rbg/article/view/8164/7444

Naranjo, J.A. \& Stern, C.R. (2004). Holocene tephrochronology of the southernmost part $\left(42^{\circ} 30^{\prime}-45^{\circ} \mathrm{S}\right)$ of the Andean Southern Volcanic Zone. Revista Geológica de Chile, 31(02), 225-240. doi: 10.4067/S0716-02082004000200003

Ramírez, J. D. V.; Carvalho, M. A.; Trindade, V. S. F.; Silva, S. M. O. A.; Lima-Filho, M. (2018). Mudanças Paleoambientais Baseadas em Palinofácies do Intervalo Albiano - Maastrichtiano da Bacia Pernambuco, Nordeste do Brasil. Anuário do Instituto de Geociências, 41(3), 186-194. doi: 10.11137/2018_3_186_194

Ruiz, I. S.; Flores, D.; Mendonça-Filho, J. G.; Hackley, P. C. (2012) Review and update of the applications of organic petrology: Part 1, geological applications. International Journal of Coal Geology, (99) 54-112. doi: 10.1016/j.coal.2012.02.004

Sallum, A.E.M; Sallum-Filho, W.; Suguio, K.; Babinski, M.; Gioia, S.M.C.L.; Harlow, B.A.; Duleba, W.; Oliveira P.E.; Garcia, M.J.; Weber, C.Z.; Christofoletti, S.R.; Santos, C.S.; Medeiros, V.B.; Silva, J.; Santiago Hussein, M.C.; Fernandes, R.S. (2012). Geochemical evidence of the $8.2 \mathrm{ka}$ event and other Holocene environmental changes recorded in paleolagoon sediments, southeastern Brazil. Quaternary Research, 77(01), 31-43. doi: 10.1016/j.yqres.2011.09.007

Souza, T. C. S.; Carvalho, M. A.; Dias, F. F.; Barreto, C. F.; Freitas A. S.; Alencar, J. W. (2016) Analysis os particulate organic matter in Holocene sediments of coastal plain from Pero Beach, Cabo Frio, Rio de Janeiro, Brazil. Journal of Sedimentary Environments, 1(2), 242253. doi: 10.12957/jse.2016.23096

Stríkes, N.M.; Cruz, F.W.; Cheng, H.; Karmann, I.; dwards, R. L.; Vuille, M., Wang, X.; Paula, M.S.; Novello, F.S.; Auler, A.S. (2011). Abrupt variations in South American monsoon rainfall during the Holocene based on a speleothem record from central-eastern Brazil. Geology, 39(11), 1075-1078. doi: 10.1130/G32098.1

Stuiver, M., Reimer, P.J., Bard, E., Beck, J.W., Burr, G.S., Hughen, K.A., Kromer, B., McCormac, G. van der Plicht, J., Spurk, M., (1998). INTCAL98 Radiocarbon Age Calibration, 24000-0 cal BP. Radiocarbon 40(3), 1041-1083.

Tyson, R.V. (2012). Sedimentary Organic Matter: organic facies and palynofacies. Springer Science + Business Media. doi:10.1007/978-94011-0739-6

United States Environmental Protection Agency - USEPA. (2002). Methods for the determination of Total Organic Carbon (TOC) in soils and sediments. Ecological Risk Assessment Support Center. NCEA-C1282. Office of Research and Development, Las Vegas.

\section{License: Creative Commons CC BY 4.0}

This article was published with open access for distribution under the terms of the Creative Commons Attribution License, which allows unrestricted use, distribution, and reproduction in any medium, provided the original work is properly cited. 